\title{
Language hybridity among Nepali Twitter users: Trend and possible implications
}

\author{
Ganga Laxmi Bhandari \\ Tribhuvan University, Nepal
}

\begin{abstract}
In Nepal, Twitter has recently been one of the fastest means of communication and information sharing app. This social networking site is used to express ideas, communicate messages, dispute opinions and expression of others and vent frustrations. What is striking is the use of hybridity or bilingualism in tweets in which Nepali and English are used freely and almost inseparably not just in chitchats but also in communicating information of public importance. Curious to see if such hybridity has the potential to contribute to changing perspectives on teaching and learning English, a brief study was undertaken in November-December 2018 as well as in June 2019. The study included selection of random tweets within the specific period of time and their analysis in terms of the currency and diversity of opinions expressed. The results show that hybridity is popular among Nepali tweeters not just in casual expressions, but also in serious communications, such as in formal complaints/notices, advertisements and commentaries on issues of public concern. The result also indicates that the ELT community cannot remain aloof of the language pattern
\end{abstract}

Key words: Hybridity, Bilingual/Multilingual turn, Virtual learning, Internet linguistics

\section{Introduction}

Social networking sites, such as Facebook and Twitter, consume much of our time these days. Most of the people are found busy with their mobile sets, checking messages from friends and colleagues, reading news from around the world and even academic materials, such as research articles and books. These virtual networking sites have taken over the physical space of social engagement, communication and critical discussion. Among social networking sites, Twitter, also known as a microblogging site, allows the users to post messages and interact with other users through posts, not exceeding 280 characters, known as "tweets". Invented in March 2006 in California, USA, the Twitter is used by over 330 million people in the world, including celebrities, religious leaders and political leaders, as 
of the first quarter of 2019 (Clement 2019). Around 6,000 tweets are posted every second and 500 million every day (Cooper 2019)

Crystal (2011, p.52) demonstrates that Twitter has been the main platform to generate Internet 'linguistics' by introducing a linguistic variety that "no other use of language" does. Twitter technology "combines identity and message in the tweets" and "displays messages with the kind of internal structure" that cannot be seen in a standard formulation (ibid).

Curious to see more about the nature of hybridity in the tweets and their possible implications for English language learning and teaching, a mini research was undertaken as a part of MPhil study in November and December 2018 and followed it up in June 2019. This piece is the outcome of the study.In this article, hybridity has been defined as the mixture or mingling of English and Nepali language (words) in tweets.

\section{Background}

We are no more in a monolingual world (Edwards, 2010). Today, linguistic diversity is celebrated as "key determinants of wealth creation, social transformation and human development" (UNESCO, 2015). In Nepal, the internet has been an engine to promote such diversity over a decade now. With the onslaught of cable and fiber networks and the availability of mobile-based internet, people from different parts of Nepal and different walks of life are connected daily (Neupane, 2018). The Internet has broken all boundaries of geopolitics, ideologies and cultures that used to divide and differentiate people, and has provided opportunities for virtual connection, interaction, information storage and sharing.

As interconnectedness grows and people start to use the space provided by the Internet, they are influenced by the experiences, ideas, worldviews and cultural practices of the member of the Internet community. They go global rising above the confines of their culture, social worldview and even ideological orientation. The Internet has thus triggered a rapid shift from 'uni-' to 'multi-' among its users at the least and established "superdiversity" by bringing together multiple nationalities, ethnicities, languages, religions and so on (Blommaert \& Rampton, 2011). The convergence of multiplicities can be seen in personal posts, such as blogs, photos, posts and tweets on Facebook and Twitter, the most popular social media and networking sites. These posts and expressions follow a particular style of composition and expression; thereby giving rise to a new branch of linguistics, which Crystal (2011) calls "Internet Linguistics," which is completely different from standard or mainstream linguistics syntactically, semantically and even orthographically.

The Internet has now been what Ivkovic and Lotherington (2009) call as "the virtual linguistic landscape," which operates much in the same way as in the physical linguistic landscape engaging multiple language users of multiple socio-economic background with different level of technological knowhow 
in constructing a language influenced by the ideas, word views and artistic posts of other language users. The Internet has, thus, been a platform of 'super-diversity' where people of different ethnicities, geographies, cultures, ideologies and so on interact and counteract (Vertovec 2019).The Internet has been a superdiverse universe in the virtual world, with Twitter being as one of the virtual communication tools.

Nepal entered this virtual world in 1993, when the Internet was introduced as a joint venture of "the Royal Nepal Academy of Science and Technology (RONAST) and a private company, Mercantile Office Systems (MOS)" (Montgomery, 2002). Initially, the Internet was only for the use of RONAST. A year later, in 1994, the Internet was available commercially. Now, according to Internet World Stats (2019), 16 million Nepali people, 54 percent of the total population, use the Internet. In 2000, only 50,000 Nepali people had access to the Internet. In 19 years, the number of the users has risen 324 times. The data suggest that the Internet users have significantly increased over the years in Nepal. So has been the number of users of online platforms, including Twitter.

Since the end of the 1990s, Internet was also used as teaching and learning tool in Nepal as part of online and distance education. In 2016/2017, Nepal was one of the 15 countries doing comparatively well in E-learning, with more than 15\% of the learning market occupied by online education (Shakya, Sharma and Thapa, 2017, p. 12). Despite challenges, attraction towards online learning, also called variously as E-learning and distance learning, is increasing day by day (Parajuli 2019).

Twitter has not been used as a teachinglearning tool in Nepal yet. However, it is important to see how Nepali tweeters participate in the virtual communication and whether it has any pedagogical implications.

\section{Objectives}

The objective of the study was to see the trend and pattern of hybridity among Nepali tweeters and its potential contribution to changing perspectives on teaching and learning English. Central to the objective was to gauge whether hybridity was just a casual phenomenon, restricted to a particular group of users and to specific genres or themes of communications, or it was a mainstream phenomenon to communicate issues of everyday importance.

\section{Research paradigm and methodology}

The study has followed the interpretative/constructivist paradigm to analyse and interpret the data. The paradigm is chosen because of its philosophical postulation that reality or truth or meaning - is constructed by individuals based on their interaction with the issue at hand (Gray 2004, p.17). In natural sciences, reality/truth is expected to exist 'out there' for a researcher to be discovered. In social sciences, however, reality/truth should be explored, unpacked, constructed and 
interpreted "through the perceptions and experiences of the participants," whether it is in the physical world or in a virtual setting (Thanh and Thanh, 2015, p.24). To paraphrase Thanh and Thanh (2015) in the context of the study, every tweet has its essence and meaning, and it should be taken as a serious source of data.

The study builds on a qualitative research design, a design that allows the study of the "meaning of people's lives, under real-world conditions" which are free of "the confines of a laboratory or any laboratory-like setting" (Yin 2011, p.8). In addition, qualitative research "can represent the meanings given to real-life events by the people who live them [and] not the values, preconceptions, or meanings held by researchers" (ibid).

The data have been analysed and interpreted using the concepts of "virtual learning and learning virtually" explained respectively as learning from "computer-based learning environments" as well as from "any context that allows for imaginative possibilities and interpretations," including through interactions with such objects as "paintings, prints, photographs..." and other facets of "the curriculum of life" (Weiss, 2006, p.xx). The tweets, the sources of data, are part of this 'facets of the curriculum of life' that freely emerge in the minds of the participants - the Nepali tweeters - and are expressed virtually to communicate the intended message.

\section{Data collection procedure}

Data for this study was collected twice. First, it was collected over a period of seven days between 30 November and 5 December 2018. Each day, roughly one hour was spent to read random tweets to see the currency of hybridity - or linguistic diversity or multilingual practice, which are used interchangeably in the article. Multilingual posts were documented through screenshot. Each day some four to five posts were, thus, collected. Second, in the third week of June 2019, six months after the first lot of data collection, two days were spent, one hour per day each evening, to review hybrid tweets. The intention now was to see if the pattern of hybridity was still on, and, if it was, whether there were additional topics being dealt with.

Diversity of users and themes (such as, politics, entertainment, education, and so on) were taken into consideration to collect the posts. Selection of posts was purposively done based on the tweets available at the particular time. Efforts were also made to see if language diversity was seen in standard communication, such as in newspapers or by public institutions/agencies in their formal communication.

Altogether, 50 random tweets were collected for analysis. The collection was purposive in the sense that only the tweets with hybridity of language were collected. The collected tweets were then clustered thematically before being analysed. The identity of tweeters was not disclosed on ethical grounds where the tweeters were identified. Pseudo identity of tweeters were however retained. 


\section{Analysis and interpretation}

The data collected suggest that Nepali Twitter users are going hybrid. The tweets relate to everyday issues that range from love, politics and social life to the failure of governments to deliver. Hybridity is seen not only in casual posts, but also in standard communications, such as in titles of online papers, that use English words in Nepali fonts suggesting the increasing rise of "contact literature" (Kachru and Nelson, 2006, p 110) in the Nepali language where English words and its literary heritages are used freely, and accepted as such, to convey a meaning in a Nepali context.

Even a cursory look at the limited data suggests that Nepali Twitter users are immensely contributing to what Phyak (2015) calls as an "ideospace ... a space where multiple language ideologies are constructed and contested." The 'ideospace' is being created through virtual interactions involving 'tweets', 'retweets', 'likes' and reactions to the tweets and retweets. The 'ideospace' in the virtual world clearly indicates that Nepal's linguistic landscape is about to take what May (2014, p.1) calls as a "multilingual turn" marked by "dynamic, hybrid, and transnational linguistic repertoires of multilingual speakers in rapidly diversifying urban conurbations worldwide."

Nepali Tweeter users are creating their own 'Internet linguistics' by enriching the

आजको लेख:
Nepali language borrowing freely from English and enhancing ownership and acceptability among general users of the borrowed language. The acceptability is not just at the morphological level, but also at syntactic and semantic levels.

The analysis of the data points to following features and trends.

Pahilo Post, an online portal, used two English words in its 11-word title in relation to the murder, after rape, of Nirmala Panta, which has been a mysterious case in Nepal for a

\section{PahiloPost $\$$ @PahiloPost · 2h}

एक युवतीको $३ ०$ सेकेन्दको 'बाइट' जसले निर्मला प्रकरणमा दियो महत्त्वपूर्ण क्लु (\#WhoKilledNirmala श्ड़खला १?)

year now. 'Bite' and 'clue' have inseparably been embedded to the title that reads 'a woman's 30-second bite gave an important clue to the investigation into the Nirmala incident.'

सरकारले कुन नीतिका आधारमा निमन्त्रणापत्र लेख्यो ? प्रधानमन्त्रीले कसैका लागि प्रोक्सी भएर काम गनु भनेको राष्ट्रिय लज्जाको विषय हो। सार्वभौम संसदले यसबारे विस्तृत जानकारी मानुपर्ष, स्वतन्त्र छानबिन गर्नुपष्ठ। kantipurdaily.com/opinion/2018/1...

A noted Kantipurdaily journalist uses a heavy English word - proxy - in their criticism of Prime Minister [Oli]'s invitation to participants of a Churchrelated event in Kathmandu, and calls on sovereign parliament to investigate the issue of what they call a national shame. There is no popular Nepali word for 'proxy.' Wares is close to it but is used mostly in the field of law. It is not in the everyday use. Wares would not get the 
punchy attention 'proxy' would get, hence the choice of this word.

Introducing an article on federalism, while taking bath in the Bagmati River and post. Needless to say, 'selfie' has become both an English and Nepali lexicon.

SajhaPost, an online paper, uses 'identity' as a Nepali word to say that no debate on identity is free and unbiased. SajhaPost's भखर टाईमलाईन हेरेपछि धेरे ट्विटे आईफोनका धनी भएको थाहा भयो, केही डाटा जोगाउन ट्विटर लाईट चलाउने रहेछन। बाँकी केही चाहिँ म जस्तै एन्ड्रोईड मोबाइल प्रयोग गरेर ट्विटरमा बरालिने रहेछन् !

use of 'identity' instead of 'pahichhan', the Nepali word for 'identity,' is an indication that 'identity' is getting more traction than its Nepali version.

The tweet below is more prominent in terms of hybridity. It coins a hybrid noun for Nepali tweeters as 'twite,' localizing the English word, and freely uses English words in the tweet that suggests many tweeters own an iPhone,

SajhaPost @sajhapost · Jun 20 यी कुनै पनि उदाहरण आइडेन्टिटीको बहससँग स्वतन्त्र र मुक्त छेनन् । अधिकार बिना स्वायत्तता, स्वायत्तता विना स्रोत परिचालन, स्रोत परिचालन विना विकास र समृद्धि असम्भव कुरा हो । sajhapost.com/2019/06/20/181... @NayaShaktiNEP unlike the tweeter, and some use tweeter light to save data. Some others, like the tweeter, use the android mobile to loiter
These three posts are examples of linguistic hybridity winning hearts and minds of the Nepali readers in the mainstream of virtual communications.

\section{b. Tweets with Nepalised English}

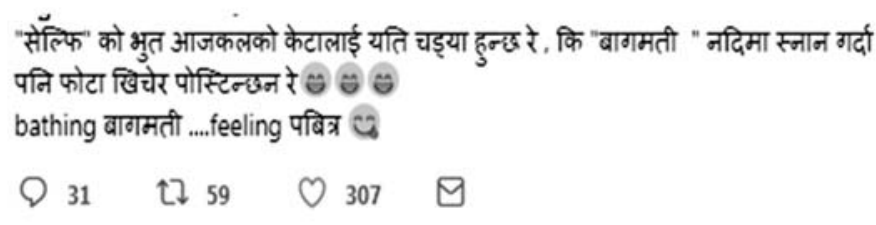
in the world of Twitter. The significance of these tweets is not just that they are light and joyful to read, but that they indicate the corruptible nature of language, a nature on which a language thrives by way of stealing, borrowing, imitating, copying and modifying, among many other ways (Allan 2013).

\section{c. Bilingual tweets in emotive expressions}

In a two-line tweet posted by a tweeter, three languages have been used: Sanskrit, Nepali and English. What is particularly interesting is the use of a Nepalised English verb, which seems to have gone well among the readers as the post has received 31 replies, 59 retweets and 307 likes. The post mocks young boys' penchant for selfie suggesting that they go so mad that they take a selfie
A tweeter struggling to apply a theoretical frame to his thesis vents their frustration in a bilingual tweet inserting a smiley emoji to make the expression more attractive. "It is not necessary to apply theory to write a thesis," says the tweeter. "A thesis can be made [written] without a theory..." In the 22-word tweet, six are English words that flow easily with Nepali words.. 


\section{Thesis लेखन theory लगाउने पर्छ भन्ने छैन विना theory नि thesis बन्छ चाहे त्यो आफे create गरेको theory नै किन नहोस! :ं शुभदिन!}

\section{Q 1 โป 1 O 2}

The contender of Miss World 2018, appeals, in a bilingual tweet, her followers to follow her and retweet her tweets to ensure the votes she needed to win the miss world title. Her appeal reads "Please follow and retweet as भस्मे QiBhasme - Dec 4 मेरो Crush ले नापतौल विभागमा काम गर्दि रहिछे।मेले propose गर्देको level मिल्दैन भन्छे है द्ड द.

Q 6 โ
much as possible. It is your responsibility for me to crown miss world. So is to introduce Nepal to the world." As can be seen in the tweet, Shrinkhala has freely used 'follow', 'Retweet', 'miss world' and 'photo,' with Nepali lexicons in a manner they work in full compatibility to express the intended semantic content.

In a metaphorical post, Bhasme shares its frustration about its crush not beeing

Follow गर्नुहोस् धेरे भन्दा धेरे Retweet गर्नुहोस् मलाई miss world बनाउने तपाईंको जिम्मा, हाम्रो देश नेपाल लाई विश्व सामु चिनाउने तपाईंको जिम्मा मलाइ बिस्वास छ तपाईंहरुले यो photo २० हजार Retweet गर्नुहुनेछ ।

interested in him/her. In the twosentence tweet of 14 words, three words are in English. It has drawn 31 retweets and 113 likes. "My crush works at the Department of [Nepal] Standards and Metrology," reads the tweet. "I proposed her, but she refuted saying it does not balance." Some sort of semantic and pragmatic hybridity can also be seen here in the putting together used to mean both 'weighing machine'

Similarly, Lamjunge Thito $\{$ Kale $\}$ blames 'slow motion (speed)' of Internet for slowing down the speed of his virtual love-chat. And, the following tweet by Hasili mocks their status of being 'single' and satirically puts that Ncell may one day put up an automated voicemessage to press 1 for 'love marriage' and 2 for 'arrange marriage.' The bilingual tweets are significant in their purported aim of drawing public attention towards the state of online service through the tweets that appear to be funny and, as such, engaging. and one's 'level (standard)'. 
साहे सिङ्ल भैयो कुने दिन त Ncell ले पनी dear customer love marriage को लागी 1

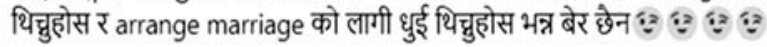

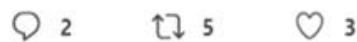

\section{d. Hybridity in Expressions of Serious Concerns}

Hybridity also seems to be common in tweets that

comment on सिनामङ्गल (काठमाहों-९),मयुरगल्ली टोलमा खानेपानीको कष्ट बिषयमा हेलो सरकारले

matters that लेखिदिएको थियो। हामीले पनि खानेपानी अफिसका उच्च अधिकृतहरु सतीशकुमारजी, डोलप्रसाद deserve serious चापागाईजी र गुनासो अधिकारीलाइ मेसेज पठायों; तर उहाँहरुले रेस्पोन्स गन्नुभएन। @PM_Nepal attention and

contemplation. A tweeter creates a diloagical conversation

\section{चर्च आयोजित 'समिट' पछ्छिको सन्दर्भ :}

अस्पतालमा विरामी हेर्न पुगेका २ पूर्वमन्त्री बीच क्यानटिनमा भेट भयो काँग्रेसी भूपूले माओवादी भूपूलाई सोधे: के छ कमरेड हालचाल ? उत्तर बनिबनाउ जस्ते रहेछ; आयो : 'रेड' खुस्किसक्यो, 'कम' बाँकी छ

\section{\#सत्यकथा}

engaging two former ministers, one from Nepali Congress and the other from the Maoists, about social criticism that erupted after the Church-organised summit in Kathmandu. The dialogue mocks the commitment to secularism of the Left parties, now in government, as they hosted and participated in the Asia Pacific Summit hosted by the South Korea-based Universal Peace Federation (UPF), a religious organisation, in December 2018. "The 'red' of the comrade has already faded," says the tweet relating to the left parties' participation in the summit, which was hosted locally by the Nepal government (Budhathoki 2018). The 'red' in the tweet refers to secularism, to which Nepal's left parties, including those in power, are rhetorically committed. But in practice, they indulge in religious activity of the kind seen in the hosting of the Church-based summit. Particularly striking is the use of 'summit,' a standard English word, in the tweet as if it were a common Nepali word.
A tweeter registers an objection, in a hybrid tweet, at the Prime Minister's Office against the shortage of water supply at the Mayurgalli Tole of Sinamangal,Kathmandu. The objection is about the lack of response from concerned officials. "Hello Sarkar had referred the matter to the office of Drinking Water. We had also sent a message to the offices' high oficials. But they didn't respond." This tweet borrows 'message' and 'response' into Nepali.

Twitter has also been a means to express serious linguistic content, as the tweet below suggests. A tweeter shares their anger at those who do not care for grammatical and semantic correctness in their writing and, thus, fail to respect the sanctity of linguistic appropriatness. The tweet has been liked by 524 followers, and retweeted nearly by 100 . Interestingly, it uses 'commonsense' as a Nepali word while advocating for linguistic purity. 


\section{१. शुद्ध लेखन नसक्नु भाषाको, व्याकरणको वा 'युनिकोडको' समस्या होइन, लेखनेको समस्या हो। २. अक्षर हेरेर पढ़नु ₹ कमनसेन्स लगाउनु शुद्ध लेखने दुईटा मुख्य उपाय हुन्। \\ ३. भाषाप्रति आदर हुनेले शब्दकोश हेरेर र सोधेर पनि शुद्ध लेख्ठ। \\ ४. हरेक शब्द अशुद्ध लेखनेका ठूला कुरा पत्याइन्न!}

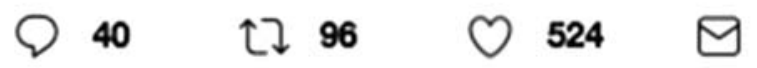

A tweeter mocks the discrimination between Nepali people and foreigners in a restaurant sharing their experience in a multilingual tweet. The tweeter was waiting for food at a corner of a room. At the other corner was a foreigner. The waiter at the restaurant brought a heater for the foreigner, and not for the Nepali tweeter. "Fine, as a Sanskrit adage goes, guests are like gods and should be treated with care and Victor Fust @ FustVictor respect. But I बुद्धिसागरले चोर्न त चोर्नु हुन्छ तर मिलाएर चोर्नु हुन्छ। अरुले Head or Tail चोर्दा टाउको कि am also a guest पुच्छर भनेर चोर्छन, बुद्धिसागरले त्यसलाइ गाइ कि त्रीशुल बनाएर नक्कल गर्नु हुन्छ। त्यसेले and am paying for the service उहाँमा निहित Localization गुणको म तारिफ गर्दछु।
Victor Fust seemingly takes up the issue of plagiarism in a three-sentence tweet. It satirically appreciates the plagiarising skills of Buddisagar, probably a writer, who artfully plagiarises using local metaphors. His skills of 'localisation' in plagiarism are quite different from others who plagiarise completely, from head to tail. It is a light tweet on a burning issue of the day. [like the foreigner]. Why this discrimination?," asks the tweeter. In protest, he paid a good amount of tips to the waiter and told him that such discrimination should not occur. 'Restaurant', 'heater' and 'tips,' the words used in the tweet, are already assimmilated into the Nepali language. So is the Sanskrit adage: athithi debo bhawa.

रेष्टुरामा खाना कुर्दे थिए। अको कुनामा एक बिदेशी देखे। शभाईले हिटर बिदेशीको अगाडी राखे। लाग्ये अतिथि देवो भव ठिक छ। फेरी सोचे म उतिनै पैसामा सेवा लिईरहेको छु भने यो बिभेद किन? ₹ मैले अरुवेला भन्दा रात्रो टिप्स दिएर भाईलाई संझाएर हिंडे।र मलाई उन्को मुस्कानले भने पछ्याइरह्यो!!!
3
ใป 3
O 45

\begin{abstract}
A tweeter warns fake Twitter handles, engaged in unfair or malicious posting, that their identity cannot be protected by using a fake handle. They can be traced from the devise they use and can be charged under cyber crime. "Using a mask does not change one's face," says the tweet. It is a warning to the trolls as well as an expression of the fact that online spaces, such as the Twitter, are not free from malicious people. It contributes 'fake handle', 'cyber crime' and 'device' to Nepali lexicology.
\end{abstract}


मसँग रिस उठे पनि कृपया फेक ह्यान्डलबाट नअ०उनु होला;पहिचान सहित आए पनि मलाई रिस उठ्देन ! मलाई त दुस्मन पनि "अोकात" हेरेर मात्र बनाउन मन लाग्छ ! फेक बाट आएर पहिचान लुक्देन;साइबर क्राइममा तपाईको पहिचान तपाईले प्रयोग गर्ने डिभाइस बाट पत्ता लाग्छ ! मुकुन्डो लगाउदेमा अनुहार फेरित्न;
() 8
个า. 11
(M) 46
M

हैंसिली कान्छी अ33 @friendly_kanxi·12h

कसेलाई जातीयताको नाममा होस्

या

अरु कुने नाममा होच्याएर बोल्दा केही बेर मनोरजन महसुस त गर्नु होला तर तपाईले

\#बोल्दालेख्दा मनोरज्जन महसुस गरेको \#शब्दले ने अरुको जीन्दगीमा उथलपुथल मच्चिन सक्छ उस्ते मान्छे त depressionमा जान नि सक्छs०अरुलाई होच्याउने काम नगरी $\checkmark \mathrm{t}$ e a c h i n g learning can be $\mathrm{m} \quad \mathrm{o} \quad \mathrm{r}$ e participatory than traditional t e a c h i n g learning as virtual learning environments allow free thinking and free flow of ideas, and enable all participants to participate freely and equally. In virtual setting, there will be no hesitation or other forms of psychological obstructions as in the formal traditional setting. Researchers in other contexts have found "virtual reality environments" to be more effective than in traditional settings as virtual environments promote constructivist activities and learner engagement as opposed to other environments (Lin and Lan, 2015). Given the increasing number of students having access to the Internet, Nepal has arrived at a point to seriously think about this alternative mode of teaching and learning.

Second, linguistic homogeneity seems to be a thing of the past among the Nepali tweeters, as diversity runs through almost all themes of everyday, private and public, life as depicted in the tweets presented above. Bilingualism is not limited to causal posts or reactions. Matters related to public concern and interest are also found to be expressed 
in a hybrid language. The only reason behind the use of hybridity is, one can argue safely, to draw public attention to the matter being discussed and bring the content to as many readers as possible. One can also argue, with caution, given the limited size of the data, 'hybridity' is preferred to 'purity' in informal communications. If this is the case, and since language develops in an informal setting, a formal teaching-learning exercise should also reflect this natural phenomenon of linguistic development.

\section{Conclusion}

A few suggestive conclusions can be drawn from this mini research. First, if these tweets are any guide, Nepal's linguistic landscape has already taken a bilingual turn at least in the virtual world. Increasing use of hybrid and bilingual contents in the Twitter, to which the study is confined, indicates this turn. Hybridity is seen not just in casual contents, but also in serious communications, such as in formal complaints/notices, advertisements and commentaries on issues of public concern. The English language teaching and learning community in Nepal cannot remain aloof from this reality in the virtual world, which is taking over the physical teaching learning setting.

Second, the notion of linguistic purity, which promotes the ideology of monolingualism and overwhelms the teaching learning activities now, does not appear to be the case in the informal world of linguistics, such as the cyber world. If a language develops and survives in an informal setting, the informality should find way in a formal teaching-learning process about it. Teaching-learning contents can be 'pure' or 'formal' or 'fixed', but teaching methods can be informal. The dominant 'English-only' notion, or Nepali-only notion for that matter, does not reflect the reality of everyday language use in Nepali contexts where classrooms are multicultural and multilingual.

Third, given the increasing popularity of social networking sites, such as Twitter, for communication and exchange, the use of such sites can be effective for teaching learning activities. Put differently, Nepal's English language teaching and learning community should initiate a virtual teaching-learning process to reflect the increasing trend of language use and development in the virtual world.

And fourth, it is about time that we in Nepal initiated a serious discussion on and preparation for virtual teaching and learning. There is no option but to prepare for such a shift given the expansion of the virtual space going beyond all traditional borders. We need a policy, curriculum and resources as soon as possible.

\section{References}

Acharya, U. (2015). Nepal twitter users survey 2015: Summary of the findings. Kathmandu: Center for Media Research Nepal

Allen, K. (2013). The Oxford handbook of the history of linguistics. Oxford: Oxford University Press 
Blommaert, J. and Rampton, B. (2011). "Language and superdiversity". Diversities. Vol. 13, No. 2, 2011. UNESCO. ISSN 2079-6595. Retrieved on 12 January 2019 from www.unesco.org/shs/diversities/ vol13/issue2/art1

Budhathoki, A. (2018). "The Asia-Pacific summit 2018 and civic dissent in Nepal." The Diplomat, 11 December 2018. Retrieved on 11 January 2019 from https:/ / thediplomat.com/2018/ 12/the-asia-pacific-summit-2018-andcivic-dissent-in-nepal/

Clement, J. 2019. "Number of monthly active Twitter users worldwide from 1st quarter 2010 to 1st quarter 2019 (in millions)." Statista, 14 August 2019. Retrieved on 12 September 2019 from https:/ / www.statista.com/statistics/ $282087 /$ number-of-monthly-activetwitter-users/

Cooper, P. (2019). "28 Twitter statistics all marketers need to know in 2019." Hootsuite, 16 January 2019. Retrieved on 12 September 2019 from https:/ / blog.hootsuite.com/twitter-statistics/

Crystal, D. (2011). Internet linguistics: A student guide. London and New York: Routledge

Edwards, J. (2010). Language diversity in the classroom. Bristol, Buffalo and Toronto: Multilingual Matters

Gray, D. E. (2004). Doing research in the real World. London: Sage

Internet World Stats. (2019). “Asia Internet use, population data and Facebook statistics - March 31, 2019." Internet World Stats. Retrieved on 15 April 2019 from

https:// www.internetworldstats.com/ stats3.htm

Ivkovic, D. and Lotherington, H. (2009). "Multilingualism in cyberspace: Conceptualising the virtual linguistic landscape." International Journal of Multilingualism, Vol. 6, No. 1, February 2009, pp. 17-36. DOI: 10.1080/ 14790710802582436

Kachru, Y. and Nelson, C.L. (2006). World Englishes in Asian contexts. Hong Kong: Hong Kong University Press

Lin, T. J., \& Lan, Y. J. (2015). “Language learning in virtual reality environments: Past, present, and future." Educational Technology $\mathcal{E}$ Society, Vol. 18, No 4, 486-497.

May, S. (2014). "Introducing the 'multilingual turn.'” In May, S. (Ed.) The multilingual turn: Implication for SLA, TESOL and bilingual education, pp. 1-6. New York and London: Routledge

Montgomery, L. (2002). "NGOs and the Internet in Nepal." Journal of ComputerMediated Communication, Volume 7, Issue 2, 1 January 2002. Doi.org/ 10.1111/j.1083-6101.2002.tb00141.x

NepaliTelecome. (2018)."Internet users in Nepal increases rapidly, penetration reaches 63 percent." NepaliTelecome, 12 March 2019. Retrieved on 20 April 2019 from https:// www.nepalitelecom.com/2018/01/ internet-in-nepal-users-rapidincrease.html

Neupane, N. (2018). 'Nepal added over 250 Internet users per hour.' The Kathmandu Post, 20 January 2018. Retrieved on 15 January 2019 from http:// kathmandupost.ekantipur.com/ 
news / 2018-01-20/nepal-added-over250-internet-users-per-hour.html

Parajuli, S. (2019). "Echoes of Darchula." Open learning exchange (OLE) Nepal. Retrieved on 15 April 2019 from https://blog.olenepal.org/index.php/ archives/2793

Phyak, P. (2015). “(En) Countering language ideologies: Language policing in the ideospace of Facebook." Lang Policy, November 2015, Volume 14, Issue 4, pp 377. Doi.org/10.1007/ s10993-014-9350-y

Shakya, S., Sharma, G. and Thapa, K. B. (2017). "State education system with Elearning in Nepal: Impact and challenges." Journal of the Institute of Engineering, Vol. 13, No. 1, pp. 10-19. Doi.org/10.3126/jie.v13i1.20344

Thanh, N. C. and Thanh, T. T. (2015). "The interconnection between interpretivist paradigm and qualitative methods in education." American Journal of Educational Science, Vol. 1, No. 2, 2015, pp. 24-27. Retrieved on 10 July 2019 from http://files.aiscience.org/ journal/article/html/70380008.html

UNESCO. (2005). A decade of promoting multiculturalism in cyberspace. Paris: UNESCO. Retrieved on 15 January
2019 from http:/ / unesdoc.unesco.org/ images / 0023/002327/232743e.pdf

Vertovec, S. (2019). "Talking around superdiversity." Ethnic and Racial Studies, Vol. 42, No. 1, pp. 125-139. Doi: 10.1080/01419870.2017.1406128

Weiss, J. (2006). "Introduction: Virtual learning and learning virtually". In Weiss, J., Nolan, J., Hunsinger, J. and Trifonas, P. (eds) The international handbook of virtual learning environments (Volume I). The Netherlands: Springer

Yin, R. K. (2011). Qualitative research from start to finish. New York and London: The Guilford Press

Contributor: Ganga Laxmi Bhandari is a Lecturer of English Education at Mahendra Ratna Campus, TU, Kathmandu .She has completed M.ED. in English Education and MA in sociology from Tribhuvan University. Currently, she is pursuing a PhD at Tribhuvan University. Her areas of interests include sociolinguistics, multilingual pedagogy and women in ELT leadership. 